\title{
Preliminary Communications
}

\section{Virulence of Temperature-sensitive Mutants of Influenza Virus}

British Medical fournal, 1969, 3, 757-758
Summary : The acquisition of temperature-mutant $(t s)$ defects in a strain of influenza virus has been shown in mice to be associated with diminished virulence, though the antibody-producing stimulus remained. It is suggested that three advantages may make $t s$ strains potential sources of attenuated live influenza vaccine-the ease of obtaining the strains, the ease of testing the vaccine strain, and the high yield of vaccine doses from a single egg.

\section{INTRODUCTION}

Early genetic experiments with influenza virus suggested that virulence for the chick embryo and mouse lung (or neurovirulence for the mouse brain) was essentially a polygenic character (reviewed by Kilbourne, 1963). Naturally occurring strains of influenza were employed in these early studies which differed from each other in a number of properties, but other than virulence and morphology all the genetic markers were concerned with virus structural proteins.

Investigations with poliovirus (Sabin and Lwoff, 1959) and encephalomyocarditis virus (Pérol-Vauchez, Tournier, and Lwoff, 1961) have shown that strains of these viruses, selected after serial passage in cells cultured at low temperatures, were much less virulent for experimental animals than the wild-type viruses. These "cold" strains were, from the nature of the isolation procedure used, multi-step mutants.

Influenza virus has been investigated genetically in this laboratory with temperature $(t s)$ mutants isolated from a single virus strain (Mackenzie, 1968). Temperature-sensitive mutants are defective in their ability to replicate in cells cultured at a high temperature $\left(39^{\circ}\right.$ C.) but give normal yields in cells cultured at a low temperature $\left(33^{\circ} \mathrm{C}\right.$.) ; they are either singlestep mutants or possibly "doubles," and the mutations responsible for the $t s$ defect may occur in any one of several different genes.

This paper reports experiments on the virulence of these $t s$ mutants for mice, and the results are discussed in terms of virus function and the feasibility of using such mutants as a basic vaccine strain.

\section{Materials AND Methods}

Viruses.-Wild-type influenza virus, strain WSN, was grown from a stock kindly supplied by Dr. R. W. Simpson. This was cloned at $39^{\circ} \mathrm{C}$. in chick embryo fibroblasts and the cloned stock designated WSNp. The isolation of the ts mutants from WSNp has been described elsewhere (Mackenzie, 1969).

Cells.-Chick embryo fibroblasts were grown as monolayers in glass Petri dishes, standard techniques being used.

Experimental Animals.-Young adult C57B1 mice, which give much more reproducible results in intranasal virulence tests of influenza virus than do stock mice (Warburton, 1964 ; N. J. Dimmock, personal communication, 1968), were used in these experiments.

Viral Assays.-Infectivity assays were carried out by plaque counts in monolayers of chick embryo fibroblasts, as reported elsewhere (Mackenzie, 1969).
Antibody Assays-Haemagglutination-inhibition tests were performed with Takátsy loops in W.H.O.-type plastic trays by the method desoribed by Fazekas de St. Groth and Webster (1966).

\section{EXPERIMENTAL RESULTS}

The parental virus, WSNp, has been shown to be lethal to C57B1 inbred mice after intranasal inoculation of $10^{4}$ plaqueforming units (N. J. Dimmock, personal communication, 1968). Mice were inoculated intranasally with the ts mutants, in groups of 10 mice for each mutant, at a dose comparable in plaque-forming units to $25 \mathrm{LD}_{50}$ of WSNp (25 times the dose of WSNp which results in a $50 \%$ mortality). The number of survivors at $6,8,10,12$, and 14 days after infection are shown in the Table. Ten of the mutants were completely avirulent, the other four ( $t s 7, t s 17, t s 18$, and $t s$ 19) were attenuated, with deaths occurring over a longer period than with WSNp.

\begin{tabular}{|c|c|c|c|c|c|c|c|c|c|}
\hline \multirow{2}{*}{ Mutant } & \multirow{2}{*}{$\begin{array}{c}\text { Cut- } \\
\text { off } \\
\text { Temp. } \\
\left({ }^{\circ} \mathrm{C} .\right)\end{array}$} & \multirow{2}{*}{$\begin{array}{c}\text { Possible } \\
\text { Defec- } \\
\text { tive } \\
\text { Func- } \\
\text { tion* }\end{array}$} & \multirow{2}{*}{$\begin{array}{l}\text { No. of } \\
\text { Mice } \\
\text { Inocu- } \\
\text { lated }\end{array}$} & \multicolumn{5}{|c|}{ Survivors after Days } & \multirow{2}{*}{$\begin{array}{c}\text { Survivors } \\
\text { after } \\
\text { Challenge } \\
\text { with } \\
100 \mathrm{LD}_{s 0} \\
\text { WSN }_{\mathrm{p}}\end{array}$} \\
\hline & & & & 6 & 8 & 10 & 12 & 14 & \\
\hline $\begin{array}{c}t s 1 \\
t s \quad 3 \\
t s 4 \\
t s 5 \\
t s 6 \\
t s 7 \\
t s 10 \\
t s 11 \\
t s 13 \\
t s 17 \\
t s 18 \\
t s 19 \\
t s 20 \\
t s 21 \\
\text { WSNp } \\
\text { Uninfected } \\
\text { controls }\end{array}$ & $\begin{array}{l}36 \cdot 5 \\
37 \cdot 5 \\
37 \cdot 5 \\
37 \cdot 5 \\
37 \cdot 0 \\
38 \cdot 5 \\
38 \cdot 0 \\
37 \cdot 0 \\
38 \cdot 0 \\
38 \cdot 5 \\
38 \cdot 0 \\
37 \cdot 5 \\
37 \cdot 0 \\
37 \cdot 0 \\
-\end{array}$ & $\begin{array}{c}\mathrm{HA}^{-} \\
? \\
? \\
\mathrm{ENZ}^{-} \\
\mathrm{HA}^{-} \\
\mathrm{HA}^{-} \\
? \\
\mathrm{HA}^{-} \\
? \\
? \\
\mathrm{ENZ}^{-} \\
? \\
\mathrm{CY}- \\
? \\
?\end{array}$ & $\begin{array}{r}10 \\
10 \\
10 \\
9 \\
10 \\
10 \\
9 \\
10 \\
10 \\
10 \\
10 \\
10 \\
10 \\
10 \\
10 \\
10\end{array}$ & $\begin{array}{r}10 \\
10 \\
10 \\
9 \\
10 \\
10 \\
9 \\
10 \\
10 \\
10 \\
9 \\
10 \\
10 \\
10 \\
10 \\
10\end{array}$ & $\begin{array}{r}10 \\
10 \\
10 \\
9 \\
10 \\
8 \\
9 \\
10 \\
10 \\
10 \\
8 \\
7 \\
10 \\
10 \\
3 \\
10\end{array}$ & $\begin{array}{r}10 \\
10 \\
10 \\
9 \\
10 \\
3 \\
9 \\
10 \\
10 \\
10 \\
5 \\
3 \\
10 \\
10 \\
0 \\
10\end{array}$ & $\begin{array}{r}10 \\
10 \\
10 \\
9 \\
10 \\
2 \\
9 \\
10 \\
10 \\
6 \\
3 \\
3 \\
10 \\
10 \\
0 \\
10\end{array}$ & $\begin{array}{r}10 \\
9 \\
10 \\
9 \\
10 \\
2 \\
9 \\
10 \\
10 \\
6 \\
2 \\
3 \\
10 \\
10 \\
0 \\
10\end{array}$ & $\begin{array}{r}10 \\
9 \\
10 \\
9 \\
10 \\
2 \\
9 \\
10 \\
10 \\
6 \\
2 \\
3 \\
10 \\
10 \\
\end{array}$ \\
\hline
\end{tabular}

$\mathrm{HA}=$ Haemagglutinin. $\mathrm{ENZ}=$ Neuraminidase
release of ribonucleoprotein from the nucleus.

The lungs of the mice which had died after infection with the attenuated mutants were removed, ground up, and titrated on monolayers of chick embryo fibroblasts, but only mutant virus could be detected. The deaths therefore were not caused by an overgrowth of revertant virus but were due to a low degree of virulence retained by the mutants.

The survivors were bled from the retro-orbital sinus 20 days after infection, and the sera tested individually for antibody to haemagglutinin by haemagglutination-inhibition. All but two mutants were found to have induced high antibody titres $(1: 80$ to $1: 1,200)$, but the survivors after infection with $t s 1$ and $t s \quad 6$ had titres of less than $1: 50$.

Twenty-one days after infection the survivors were challenged with $100 \mathrm{LD}_{50}$ of WSNp intranasally. Control mice, not previously infected, died within eight days of inoculation, but no deaths were recorded for any of the survivors over 18 days after challenge, despite the low antibody levels found for the survivors from $t s 1$ and $t s 6$ infections.

In a further experiment mice which had survived infection with $25 \mathrm{LD}_{50}$ of ts 1 , ts 3 , ts 5 , and ts 13 were challenged 32 days after infection with $500 \mathrm{LD}_{50}$ of WSNp. Once again the mice were totally protected and no deaths were recorded, whereas all control mice died. 


\section{Discussion}

It can be concluded from these experiments that the acquisition of a temperature-sensitive defect causes a decrease in virulence. A similar result has been found with $t s$ mutants of Semliki Forest virus in mice, and rabbit-pox virus in rabbits (Fenner, 1968). Nevertheless, the mutants must replicate in the mouse lung to the extent that they can induce high titres of antibody directed against the viral haemagglutinin.

It was not possible to correlate virulence with the physiological characters of the mutants (Mackenzie and Dimmock, in preparation), nor with their genetic locations (Mackenzie, 1969). Of the four attenuated mutants, only ts 7 and $t s 18$ have had defective functions assigned to them; ts 7 has been found to be defective in haemagglutinin, and ts 18 is believed to be defective in neuraminidase. Both $t s 17$ and $t s 19$ synthesized haemagglutinin and nueraminidase at the restrictive temperature. Other mutants which have defects in their haemagglutinin ( $t s 1, t s$, and $t s 11$ ) or in neuraminidase ( $t s$ 5 ) were totally avirulent. There was also no correlation between cut-off temperature and virulence, in contrast to $t s$ mutants of Semliki Forest virus (F. J. Fenner, personal communication, 1968).

It has been shown by Schulman, Khakpour, and Kilbourne (1968) that antibody directed against neuraminidase has a protective effect in the mouse lung, and this provides a possible explanation for the protective effect of $t s 1$ and $t s 6$ to subsequent challenge by WSNp despite low antihaemagglutinin antibody levels.

From the results in this communication and genetic results to be published elsewhere (Mackenzie, 1969) a hypothetical, but rational, procedure can be put forward for the production of an attenuated live influenza vaccine along the lines previously suggested by Fenner (1968). A basic vaccine strain could be produced from a recent influenza isolate $\left(A_{2}\right.$ strain) in one of two ways: either by obtaining a strain with multiple $t s$ mutations by recombining suitable single $t s$ mutants with defects in non-structural genes (double and multiple $t s$ recombinants could be verified by back-crossing) or by heavy mutagenic treatment of an existing $t s$ stock. The former technique has the advantage of being able to select for adequate growth capacity and stability of each specific $t s$ lesion to be included in the basic vaccine strain. Such a strain could be maintained easily by standard genetic methods.

The actual vaccine strain could be obtained by simple recombination between the basic vaccine strain and each new antigenic variant by selecting for the new antigenic variant with the $t s$ characteristics. Once again the stability could be verified by back-crossing to ensure the inclusion of all $t s$ lesions.

The value of this procedure is threefold. A basic vaccine strain having been obtained, the first attribute is the ease with which a suitable recombinant could be isolated (recombination occurs at a high frequency with influenza); secondly, the actual vaccine strain could very quickly be tested for reversion and stability ; and, finally, it is envisaged that up to 1,000 vaccine doses could be prepared from the yield of a single egg, in contrast to about a single dose from each egg of the currently used killed vaccines. Of course, the efficacy of such a live vaccine could be determined only by trials in man.

J. S. Mackenzie,* B.SC., PH.D. Department of Microbiology, John Curtin School of Medical Research, Australian National University, Canberra.

* Present address: Department of Urology, Public Health Research Institute of the City of New York, Inc., 455 First Avenue, New York.

REFERENCES

Fazekas de St. Groth, S., and Webster, R. G. (1966). Fournal of Experimental Medicine, 124, 331.

Fenner, F. J. (1968). The Biology of Animal Viruses, chapter 18. New York, Academic Press.

Kilbourne, E. D. (1963). Progress in Medical Virology, 5, 79

Mackenzie, J. S. (1968). Ph.D. Thesis, Australian National University, Canberra.

Mackenzie, J. S. (1969). Fournal of General Virology. In press.

Pérol-Vauchez, Y., Tournier, P., and Lwoff, M. (1961). Comptes rendu hebdomadaires des Séances de l'Académie des Sciences, 253, 2164

Sabin, A. B., and Lwoff, A. (1959). Science, 129, 1287.

Schulman, J. L., Khakpour, M., and Kilbourne, E. D. (1968). Fournal of Virology, 2, 778.

Warburton, M. F. (1964). Ph.D. Thesis, Australian National University Canberra.

\section{Antilymphocytic Serum in Experimental Allergic Encephalomyelitis}

British Medical fournal, 1969, 3, 758-760

\begin{abstract}
Summary: Antilymphocytic and antithymic sera $N$ (raised in rabbits) are highly potent in preventing or alleviating experimental allergic encephalomyelitis in guinea-pigs. Good results are obtained when treatment is begun as late as $\mathbf{1 0}$ days after challenge. No protracted disease was seen from the use of antilymphocytic serum. Attempts to use this serum therapeutically once the disease was clinically established gave equivocal results. Antilymphocytic serum appears to have a non-specific stressor effect as well as its specific action, and possibly this adrenocorticotrophic-hormone (antiphlogistic) effect may ameliorate a developing encephalitis. The presence of an antimacrophagic factor in antilymphocytic serum may be important in increasing local reaction to injection of the serum and perhaps also in diminishing the appearance of haematogenous elements in the nervous lesions.
\end{abstract}

\section{INTRODUCTION}

Experimental allergic encephalomyelitis is a disease readily produced in guinea-pigs by inoculation of whole brain or an encephalitogenic factor with Freund's complete adjuvant (Robertson et al., 1962 ; Caspary and Field, 1965). A great deal of evidence now links the experimental disease with sensitization of lymphocytes, and it is considered to be a form of delayed hypersensitivity (Paterson, 1966). Since it is also regarded by many as a model for multiple sclerosis the influence of antilymphocytic serum and antithymic serum on the condition is of importance. The present work sets out the results of experiments aimed at the prevention and treatment of the disease.

\section{Materials AND Methods}

\section{ANTILymphocytic and ANTithymic Serum}

Cervical and mesenteric lymph nodes (or thymus lobes) were removed from healthy adult Hartley guinea-pigs of both sexes, cleaned, cut up, and teased in chilled Hanks's solution. After washing, the dissociated cells were filtered through a 100 stainless steel mesh and then through an 80 mesh. Final suspensions were made up to contain about $10^{8}$ cells per inoculum $(1.5 \mathrm{ml}$.) in Hanks's solution. A dye exclusion test showed about $80 \%$ viability of lymph node cells and $95 \%$ of thymic cells.

Large adult albino rabbits were immunized by intravenous injection of the cells. This was repeated 10 days later, and five days after that the animals were bled. Further injections were carried out about every two to three weeks and $25-50 \mathrm{ml}$. 